Justyna Pilarska

E-MAIL: JUSTINE_P@OP.PL

\title{
PERSPEKTYWA INDYGENICZNA \\ W BADANIACH ŚRODOWISK ZRÓŻNICOWANYCH \\ KULTUROWO - KU METODOLOGICZNEJ \\ WRAŻLIWOŚCI KULTUROWEJ
}

\section{Wstęp}

Zgodnie z paradygmatem interpretatywnym wiedza jest kreacją ludzkiego umysłu, a więc podobnie jak fakty, zdarzenia i ludzie podlega nieustannym zmianom, mając charakter społeczny [Malewski 1998: 34]. Z drugiej strony, paradygmat krytyczny zakłada, iż badania naukowe są rodzajem praktyki społecznej osadzonej w kulturze, a badacz, jak i jego otoczenie poddawane eksploracji, wytwarzając wiedzę ustawicznie poszerzają sferę komunikacji interpersonalnej, budując krytyczną i samokrytyczną refleksję, co w konsekwencji generuje subiektywizm poznawczy i relatywizm wiedzy [Malewski 1998: 39]. Powyższe ustalenia autorka uczyniła punktem wyjścia dla refleksji nad badaniami w edukacji międzykulturowej, ponieważ tworzą one fundament propozycji - postulat badań indygenicznych, zorientowanych na dynamiczne właściwości kulturowe społeczności lokalnych, w których badacz realizuje swoje praktyki metodologiczne. Impulsem do podjęcia tej tematyki stały się własne doświadczenia badawcze związane z eksploracją bośniackiego pogranicza kulturowego, które zweryfikowały dostępny w badaniach społecznych repertuar metodologiczny. W konsekwencji, demaskując uwikłanie metodologii badań w (post)kolonialny dyskurs można $\mathrm{z}$ łatwością zdekonstruować swoistą metodologiczną praktykę dyskryminacyjną ${ }^{1}$.

\footnotetext{
1 Wielu badanych przez autorkę przedstawicieli zróżnicowanej kulturowo społeczności bośniackiej podkreślało, iż badani przez np. socjologów lub psychologów ze Skandynawii czuli się jak „króliki doświadczalne”, podczas gdy cała istota postępowania badawczego służyć miała potwierdzeniu ukrytych przypuszczeń naukowców wyrażana sformułowaniem „my wiemy, jacy wy jesteście", a badania miały tylko to potwierdzić.
} 
Badania naukowe nie przebiegają w oderwaniu od kontekstu przestrzennego czy historycznego, przez co projekty metodologiczne zorientowane na właściwości kulturowe badanych społeczności lokalnych mogą stać się antidotum na zachodnioeuropocentryczny dyskurs w nauce. Warto bowiem mieć na uwadze, iż badania to poszukiwanie nie tylko wiedzy, ale też sposobów komunikowania jej z innymi, a więc jest to sposób studiowania, analizowania, interpretowania i komunikowania kulturowo odmiennego otoczenia społeczności badanej [Sefa Dei 2013: 6].

Wnioski ze zrealizowanych badań własnych nad m.in. postawami wobec odmienności etnicznych w środowisku zróżnicowanym kulturowo na przykładzie Bośni i Hercegowiny oraz dotyczące tożsamości bośniackiej zainspirowały autorkę niniejszego opracowania do przewartościowania percepcji prawidłowości metodologicznych w środowisku zróżnicowanym kulturowo, prowadząc do przyjęcia postulatów badań indygenicznych.

\section{Postkolonialny dyskurs}

W klasycznie pojmowanej metodologii nauk społecznych wyraźna jest przewaga władzy i kontroli instytucjonalnej, często pociągającej za sobą stygmatyzację społeczną ${ }^{2}$. Ta, z kolei, podtrzymuje zakotwiczenie w retoryce homogenizacji i uniwersalizacji standardów europejskiej i angloamerykańskiej wiedzy, stanowiąc uzasadnienie dla epistemologii apriorycznych generalizacji oraz etnocentrycznej interpretacji tego, co odmienne. To, w konsekwencji, wywołuje nieufność ze strony grupy badanej, która postrzega siebie samą jako podporządkowaną imperializmowi naukowemu ${ }^{3}$, a więc uwikłaną w bezkrytyczne przenoszenie na badany grunt teorii naukowych konstruowanych na „zachodzie”, a więc poza danym kulturowym kontekstem.

Ponadto, w tak zorientowanych badaniach analizie rzadko kiedy podlegają poszczególni członkowie społeczności, bardziej są to sensu stricto kultury i ich zbiorowi przedstawiciele ${ }^{4}$, co redukuje bogactwo i złożoność

2 W myśl redukcyjnej dychotomii My, czyli „zachód”, a więc Europa, Europa Zachodnia, Unia Europejska, Oni, czyli Bałkany, Bliski Wschód, Arabowie, Daleki Wschód.

3 Opinia wyrażona przez jednego z badanych w ramach projektu badawczego „Potencjał edukacji międzykulturowej w środowisku zróżnicowanym kulturowo w sytuacji radykalizacji religijnej na przykładzie wahhabizmu w Bośni i Hercegowinie", zrealizowanego w sierpniu 2013 roku. Przykładem są tożsamości zbiorowe i metoda studium „zbiorowego” przypadku. 
otrzymywanych danych, dodatkowo implikując problem związany z generalizacją wyników ${ }^{5}$.

Podejście konwencjonalne marginalizuje różnice w identyfikacji społecznej oraz cechy indywidualne, które mogą proces badawczy wzbogacić epistemologicznie. Założenia metodologiczne mogą być bowiem miarodajne i rzetelne w zachodnioeuropejskim kontekście kulturowym, ale nie oznacza to, iż takie pozostaną w innych kulturach.

W podejściu postkolonialnym wyraźna jest również tendencja do czynienia z własnej społeczności ramy koncepcyjnej, która legitymizuje metodologiczną hegemonię, bez przestrzeni dla autonomii kognitywnej badacza. To, z kolei, zawęża pole percepcji badanych zjawisk i możliwość wglądu w istotę interpersonalnych zależności w środowisku zróżnicowanym kulturowo.

Ponadto, pojęciem postkolonialnego dyskursu posługują się badacze środowisk wielokulturowych, w których nadal uobecnia się tzw. strukturalna dyskryminacja, a więc np. etnocentryczne programy nauczania, polityka edukacyjna i metodyka instytucji akademickich. Demaskując różne praktyki dyskryminacyjne, prekursorzy podejścia indygenicznego na południowozachodnim Pacyfiku (Nowa Zelandia) i w Stanach Zjednoczonych (tzw. czarna metodologia), [Sefa Dei 2013: 177] zapoczątkowali proces włączania m.in. elementów filozofii i wiedzy Maorysów oraz Afroamerykańskich społeczności w międzykulturowy coaching, przeciwstawiając się zachodniocentrycznej dominacji w paradygmatach terapeutycznych [Stewart 2012: 27].

\section{Badania zorientowane indygenicznie}

Poststrukturalizm oraz teoria krytyczna stanowią swoiste teoretyczne umocowanie dla indygenicznego stanowiska metodologicznego, ponieważ w pierwszym fenomenie dyskurs odgrywa kluczowa rolę w procesie po-

\footnotetext{
Warto w tym miejscu zadać (retoryczne) frapujące metodologicznie pytanie, czy rzeczywiście badania w dyskursie edukacji międzykulturowej wymagają generalizacji jako warunku uprawomocnienia ich wyników? Pytanie to pociąga za sobą kwestię ekwiwalencji badanych modeli teoretycznych oraz równoważność (pod względem znaczenia i wagi) weryfikowanych hipotez w metodologii badań nad międzykulturowością. Jeśli bowiem teorie i hipotezy nie są ekwiwalentne we wszystkich badanych kulturach, to nie można porównywać zgromadzonych w nich danych, ponieważ w każdej z kultur mają one odmienne znaczenia. Por. [Padilla 2004: 127-128].
} 
wstawania wiedzy, podobnie jak „odkrywanie powiązań między poziomami mikro i makro, między potoczną wiedzą, praktykami i rytuałami życia codziennego a dyskursami władzy i kontroli” [Szkudlarek 1997], podczas gdy w teorii krytycznej „kluczowego znaczenia nabiera refleksja i samorefleksja jako czynnik i rezultat dialektycznego związku między uczestnikami sytuacji badawczej i pozostałymi jej elementami, składającymi się na świat życia podmiotów uczestniczących w procedurze" [Czerepaniak-Walczak 2010: 322]. Takie stanowisko metodologiczne akcentuje w konsekwencji dyskursywność praktyk społecznych i kulturowych badanych społeczności, a zarazem implikuje dialektykę refleksyjności i podmiotowości w procedurze badawczej.

Dlatego też, badania zorientowane indygenicznie stanowią formę rozpoznania tych obszarów kulturowych (społeczności, wspólnoty, pogranicza), gdzie uobecniają się swoiste dla tej grupy zjawiska umożliwiając rzetelny, emiczny ${ }^{6}$ wgląd, pozbawiony arbitralnych przedrozumień danego fenomenu. To w konsekwencji pozwala oddać unikatowe (niegeneryczne) i narracyjne perspektywy lokalnych zjawisk kulturowych, z poszanowaniem różnicy kulturowej i podmiotowości badanych.

Podejście indygeniczne eksponuje kulturowo uwarunkowane różnice w sposobie pojmowania świata i myślenia o członkach danej społeczności, włączając w to strukturę kognitywną (wzorce postrzegania, syntezy czy analizy wpływającej na intelektualne opracowanie konkluzji, pamięć poznawczą zdarzeń), założenia dotyczące charakteru relacji interpersonalnych, założenia dotyczące hierarchii priorytetów życiowych, preferowane wzorce wyjaśniania zdarzeń, sposób organizacji świata, stosowane zasady logiki formalnej i podejścia dialektycznego [por. Nisbett 2001: 46-47], intersubiektywne wzorce świadomości (wartości, habitaty semantyczne, praktyki kulturowe), [por. Przyborowska 2010: 439], a także postrzeganie relacji między Ja, grupą własną i grupą obcą (kategoryzacja społecznej tożsamości wobec dychotomii Swój-Obcy).

Powyższe wskaźniki podejścia indygenicznego sygnalizują, iż koncepcje mogą być zasadne jedynie w relacji do wąskiego zakresu grup kulturowych [Yoder, Kahn 1993: 846-850], nie mają więc uniwersalnego uprawomocnienia, ponieważ o ile w podejściu konwencjonalnym (postkolonialnym) teoria „zarządza” badaniem, o tyle interaktywność indygeniczna i towarzysząca jej relatywizacja narzędzi badawczych pozwala na

$\overline{6}$ W myśl założeń antropologii kognitywnej każda kultura posiada swoje emiczne konstrukty, które można ująć jako naturalne, pierwotne cechy etyczne. Por. [Buchowski, Burszta 1993: 12]. 
odkrywanie „prawd partykularnych”, właściwych danej kulturze lub grupie społecznej [Padilla 2004: 128].

Paradygmaty badawcze zakotwiczone w zachodnioeuropejskim dyskursie redukują badane kultury do nadegeneralizacji ustaleń, co nie pozwala na odkrycie istoty kulturowej danej społeczności, utrzymując uprzywilejowanie uprzednich, ukrytych założeń co do badanej społeczności ${ }^{7}$. Z kolei $\mathrm{w}$ perspektywie indygenicznej zakwestionowany zostaje prymat zachodniocentrycznego postrzegania świata i modernistycznego objęcia „wszystkich czasów i miejsc”, w myśl postmodernistycznego końca Europejskich Wielkich Opowieści, które „zachód opowiadał sam sobie, aby potwierdzić się przeciwko "reszcie «, aby umieścić się jako Mistrz i Bohater w centrum" [Hebdige, za: Melosik 2007: 183-184].

Badania w perspektywie indygenicznej to swoisty projekt etnograficzny realizowany (i przeżywany) w badanych społecznościach, przez co badacz staje się uczestnikiem i obserwatorem tych grup, akceptując fakt, iż badania nie są obiektywnie neutralne, zaś wszystkie badane fenomeny winne być postrzegane z perspektywy kontekstu, również czasowego. Dlatego też znajomość kultury badanej jest warunkiem przedwstępnym aktywności metodologicznej, bowiem przekraczając paradygmat stereotypizacji, badania wrażliwe kulturowo wymagają aktywnego uczestnictwa w kulturze badanej grupy [Rogler 1989: 296].

Mimo problemów wynikających z różnic kulturowych, na które może napotkać badacz, niezbędna jest znajomość narzędzi komunikacyjnych, oraz szerzej kompetencji interpersonalnych (tzw. soft skills) skracających dystans kulturowy i umożliwiając przeprowadzenie rzetelnych, głęboko interpersonalnych i wrażliwych kulturowo badań. Stąd też, w tak przyjętej optyce metodologicznej, niedopuszczalne są badania prowadzane $\mathrm{z}$ wykorzystaniem tłumacza jako pośrednika odkrywania epistemologicznych treści i docierania do świata przeżyć poszczególnych członków badanej społeczności. Co więcej, podczas badań terenowych obecność badacza w rzeczywistości dnia codziennego badanych podmiotów jest kluczowa, a więc jeśli tylko jest to możliwe, warto zrezygnować z zakwaterowania w hotelu na rzecz bliskiego kontaktu w bezpośrednim otoczeniu material-

Podczas badań nad postawami wobec mniejszości etnicznych w Bośni i Hercegowinie badani komentowali zaproponowane narzędzie ilościowe (kwestionariusz zamknięty) stwierdzeniem, iż „co byśmy nie zaznaczyli w tej ankiecie, i tak ostatecznie wyjdzie, to chcecie żeby o nas wyszło, a więc tylko potwierdzą się wasze stereotypy na nasz temat jako "odwiecznie nienawidzących się» narodów bałkańskiego tygla”. 
nym i duchowym badanych, zamieszkując np. w domu członków lokalnej społeczności.

Podejście indygeniczne, unikając apriorycznych generalizacji i etnocentrycznej interpretacji tego, co kulturowo odmienne, koresponduje z partycypacyjnym oglądem badań J. Herona, według którego

badacz jest w stałych interakcjach z podmiotami tak, że uczestniczą oni bezpośrednio zarówno w wytwarzaniu hipotez, jak i formułowaniu końcowych konkluzji, oraz tego wszystkiego, co się dzieje pomiędzy [...] podmiot staje się współbadaczem [...] ale także badacz jest współpodmiotem, w pełni uczestnicząc w działaniu i doświadczeniu poddanym badaniu [Heron 1991: 19-20].

W konsekwencji, w relacji badacz - badany dominuje charakter spotkania, któremu towarzyszy wysiłek odnalezienia wspólnej płaszczyzny dialogu, a obydwie strony tego spotkania zajmują podmiotowe stanowiska. A więc poprzez społeczną konstrukcję wiedzy możliwe jest włączenie badanych społeczności w planowanie i implementację projektu metodologicznego, co zwiększa międzykulturowy potencjał badań. Pozwala to też uniknąć prostej modyfikacji metodologicznej, mającej na celu weryfikację hipotez.

\section{Kompetencje miękkie w orientacji indygenicznej}

Indygeniczny ogląd badań jakościowych uwzględnia m.in. otwartość, elastyczność, kreatywność i dialogiczność badacza. W konsekwencji otwartości na nowe pomysły, idee, czy alternatywy metodologiczne, projekt badawczy staje się fenomenem dziejącym się in situ, pociągając za sobą elastyczność wyrażaną m.in. przez umiejętność zaadaptowania się do dynamicznych zmian w badanym środowisku kulturowym. Pomaga w tym kreatywność, a więc zdolność tworzenia czegoś nowego i oryginalnego, a także dialogiczność rozumiana jako wchodzenie w interakcje na etapie „precyzowania koncepcji badań, zbierania materiału, jego analizowania i interpretowania, a także sprawdzania wstępnej wersji opracowania" [Kubinowski 2010: 328].

Badacz świadomy różnic kulturowych projektując narzędzia badawcze winien również wykazać się autorefleksją, związaną z refleksyjnością i autoewaluacją, włączając w to 
dotychczasowe wyposażenie, osobiste nastawienia i zainteresowania badacza [...] aby uwzględnić różne interpretacje odpowiedzi formułowane z różnych perspektyw myślowych [...] przemyślenia i udokumentowanie zmian [...] w rezultacie realizacji przez niego danego projektu, będącego przeważnie konsekwencją uczenia się od innych [Lichtman 2010: 334].

Stąd też rezultaty badań są konstruowane na drodze społecznych i kulturowych uzgodnień między zaangażowanymi w nie osobami, a ponieważ badania środowisk zróżnicowanych kulturowo są osadzone w społeczno-kulturowym kontekście, kompetencje miękkie mogą istotnie przyczynić się do sukcesu projektów metodologicznych. Do szczególnie przydatnych właściwości badacza, oprócz otwartości, elastyczności, kreatywności i dialogiczności zaliczyć warto empatię i inteligencję emocjonalną, umiejętność rozwiązywania konfliktów, kompetencje psychologiczne tzw. relacji z samym sobą jak samoświadomość, umiejętność rozpoznawania własnych stanów emocjonalnych, wiedza o własnych uczuciach, wartościach, preferencjach, możliwościach i ocenach intuicyjnych, umiejętność radzenia sobie ze stresem, umiejętność realizacji celów społecznych, konsekwencja w działaniu, umiejętność negocjacji, wysoka samokontrola, życzliwość, towarzyskość, serdeczność w kontaktach międzyludzkich, umiejętność słuchania, metaforyczność w interpretacji świata, wyobraźnia badawcza, intuicja interpersonalna, podmiotowość i wewnątrzsterowność, a także solidarność międzyludzkå .

Jeśli badacz potrafi odkryć w sobie, wypracować lub wykształcić choć część z tych kompetencji (a zarazem wskaźników tożsamości osobowej i społecznej), zapewne odkryje to przed nim nowy obszar badawczych eksploracji, generując dialog teorii z doświadczeniami życiowymi członków badanego pogranicza kulturowego. Jak bowiem pisze E. W. Eisner:

istnieją wielorakie sposoby, poprzez które świat może być poznawany, a ludzka wiedza jest konstruowaną formą doświadczenia oraz refleksją umysłu i natury, stąd też wiedza jest wytwarzana a nie po prostu odkrywana, a więc dociekanie pedagogiczne stanie się bardziej kompletne i bogatsze w informacje, gdy zwiększymy zakres sposobów opisywania, interpretowania i oceniania świata edukacji [Kubinowski 2010: 144].

8 Powyższy zestaw stanowi jedynie propozycję wynikającą z badawczych doświadczeń autorki i jej refleksji nad omawianym zagadnieniem, ale zapewne nie wyczerpuje to możliwego repertuaru właściwości osobniczych, kompetencji i umiejętności niezbędnych do realizacji badań w perspektywie indygenicznej. 


\section{Bośnia i Hercegowina jako obszar badawczych eksploracji}

Poniższe refleksje stanowią ilustrację wrażliwej kulturowo perspektywy w odczytywaniu badanej przestrzeni wielokulturowej, która choć posiada europejski rodowód, wykazuje niezwykle „indygeniczne” właściwości.

Podczas badania pogranicza kulturowego Bośni i Hercegowiny rozpoznanie specyfiki kulturowej tego regionu jest kluczowe dla powodzenia wszelkich projektów badawczych, przez co uprzednia eksploracja cech charakterystycznych społeczeństwa zróżnicowanego etnicznie i wyznaniowo jest priorytetem. W perspektywie indygenicznej historyczny kontekst kształtowania się danej przestrzeni międzykulturowej i ewentualnych eksterytorialnych wpływów politycznych dostarcza ram koncepcyjnych, które pozwalają zrekonstruować charakter i dynamikę relacji międzykulturowych na danym terenie.

W przypadku Bośni i Hercegowiny dotyczy to m.in. niemalże pięciowiekowej okupacji tureckiej czy dominacji austrowęgierskiej, które pociągnęły za sobą zróżnicowane systemy organizacji działalności polityczno-administracyjnej, politykę wyznaniową, stratyfikację społeczną, uprzywilejowanie danych grup zbieżnych kulturowo z siłami politycznymi dominującymi w danym momencie historycznym. Wszystkie te czynniki dynamizowały powstawanie określonych stereotypów i uprzedzeń, również w stosunku do zachodnioeuropejskiego dyskursu politycznego, narzucanej struktury społecznej i standardów systemu ekonomicznego. Dlatego też zadaniem badacza jest odkrycie tych zależności przed metodologiczną penetracją badanej społeczności.

Dowodem na kulturową wyjątkowość bośniackiego pogranicza kulturowego mogą być badania G. Hofstede, dotyczące różnic kulturowych na skali indywidualizm - kolektywizm. Ten holenderski psycholog społeczny przeprowadził serię badań nad zależnością między kolektywizmem i indywidualizmem w pierwszej połowie lat osiemdziesiątych XX wieku (1980 i 1984), [Hofstede 2001]. Wyniki uzyskane na skali IK (indywidualizm kolektywizm) odzwierciedlały poziom indywidualizmu jako wartości centralnej, ujawniając jej najwyższą wartość w Stanach Zjednoczonych (91), przy średniej krajów wynoszącej 51. Najniższy wynik osiągnęła Wenezuela (12), podczas gdy Jugosławia (której jedną z sześciu republik w tamtym okresie była Bośnia i Hercegowina) osiągnęła wynik 27, podobnie jak Hongkong, Meksyk, Filipiny czy Portugalia. Warto zaznaczyć, że z krajów basenu Morza Śródziemnego, powszechnie postrzeganych jako akcentu- 
jących wspólnotowość, Turcja osiągnęła wynik 37, a Grecja 35 punktów [Matsumoto, Juang 2007: 72], co sytuuje ówczesną Jugosławię na osi indywidualizmu - kolektywizmu bliżej państw wspólnotowych, nadających priorytet wspólnocie lokalnej i więzom ponadrodzinnym. Co ciekawe, to właśnie z Turcji, która znalazła się na badanej skali bliżej osi krańcowej indywidualizmu, pochodzi pojecie komşluk - tradycji obecnej w bośniackiej rzeczywistości kulturowej, a oznaczającej dobrosąsiedzkie stosunki niezależnie od wyznawanej religii.

Dlatego też Bośnię i Hercegowinę jako obszar badań nad międzykulturowością charakteryzują w kontekście kolektywnej specyfiki kulturowej bardziej preferowanie działań zbiorowych niż swobody indywidualnego działania, pragnienie harmonijnego wtopienia się w grupę bardziej niż pragnienie wyróżniania się oraz preferowanie podejść partykularnych, uwzględniających sytuację i charakter relacji ${ }^{9}$. Badacz nieświadomy takich zależności, wchodząc w kulturową przestrzeń pogranicza bośniackiego $\mathrm{z}$ uprzednio przygotowaną metodologią zorientowaną zachodnioeuropocentrycznie, jest właściwie skazany na niepowodzenie. Stąd też, jeśli nie uwzględni uwikłania przedmiotu badań w rozmaite dyskursy kulturowe, często o charakterze „endemicznym”, właściwe jedynie badanej rzeczywistości, może popaść w pułapkę wspomnianego imperializmu naukowego, stawiającego go aksjologicznie i ontologicznie „ponad” członków badanej społeczności. A ponieważ większość dotychczasowych badań, teorii i praktyki $\mathrm{w}$ edukacji międzykulturowej są $\mathrm{w}$ kontakcie $\mathrm{z}$ różnicą kulturową zorientowane zachodniocentrycznie (western-centric dominance), może to przesądzić o (nie)powodzeniu międzykulturowego projektu badawczego.

\section{Zakończenie}

Obecnie w naukach społecznych wydają się dominować dwa paradygmaty. Z jednej strony, wyraźna jest tendencja do ujmowania prawdy i zasad jako uniwersalnych (odnoszących się do przedstawicieli wszystkich kultur), a z drugiej, priorytet nadawany jest specyfice kulturowej,

9 Wyjątkowym świadectwem tej wspólnotowej właściwości Bośniaków jest książka S. Broz [2002], w której autorka przywołuje historie z wojny w Bośni i Hercegowinie na początku lat dziewięćdziesiątych XX wieku, kiedy to przedstawiciele różnych grup etnicznych pomagali swoim sąsiadom i przyjaciołom z narażeniem życia, wbrew etniczno-wyznaniowym podziałom; 90 zebranych historii to świadectwa pomocy, której udzielali Serbowie Muzułmanom, Muzułmanie Chorwatom. 
czyli przyjmuje się, iż pozyskane wyniki są trafne jedynie w stosunku do części określonych grup społecznych należących do danych (niektórych) kultur. Zważywszy na postmodernistyczne zakwestionowanie absolutnego charakteru wiedzy generowanej na bazie europocentrycznych badań, emfaza kulturowych uwarunkowań pozwala uprawomocnić tezę, iż jeśli coś jest prawdziwe w jednej kulturze, nie musi się sprawdzać w pozostałych ${ }^{10}$. Dlatego też, „może się zdarzyć, że chociaż pewien wynik został powtórzony w badaniach z udziałem przedstawicieli danej kultury czy społeczeństwa, jednak nie jest on prawdziwy dla innej kultury czy społeczeństwa" [Matsumoto, Juang 2007: 19]. Stąd też, kryteria poprawności naukowej badań podlegają wpływom kulturowym, czyli są zmienne w zależności od środowiska kulturowego, w jakim pracują badacze.

W konsekwencji, badania zorientowanie indygenicznie wymagają:

- osobistego zaangażowania,

- intensywnej obserwacji i pracy w terenie,

- regularnego kontaktu z badaną społecznością,

- odwiedzania jej członków (życia z nimi),

- $\quad$ uczestnictwa w czynnościach dnia codziennego ${ }^{11}$,

- „zanurzenia” się w kulturze poprzez udział w jej rytuałach, praktykach dnia codziennego sfery sacrum i profanum.

W konsekwencji możliwe jest gromadzenie wiedzy „z pierwszej” ręki o obyczajach, rytuałach, praktykach, tradycjach, wierzeniach, stylu życia wizerunku kobiety, stereotypu płci.

W badaniach nad zjawiskami będącymi przedmiotem zainteresowań edukacji międzykulturowej (jak aksjologia pogranicza, tożsamość wielowymiarowa, międzykulturowe uczenie się) podejście indygeniczne legitymizuje nie metodologię przygotowaną przez badacza, lecz samo środowisko badawcze, w którym członkowie lokalnej społeczności stają się „współproducentami” wiedzy [Wilson 2008: 32]. Tym samym budowany jest kapitał społeczny oraz epistemiczna wspólnota, ponieważ tak zorien-

$\overline{10}$ Przykładem może być pojęcie solidarności międzygrupowej, które różnie uobecnia się w przestrzeniach wielokulturowych w zależności od dynamiki konstruowanych tożsamości kulturowych czy społecznych na danym pograniczu. Por. [Markešić 2009].

11 W Bośni i Hercegowinie jednym z najważniejszych rytuałów kulturowo-społecznych, wykraczających poza towarzyskie kanony, jest ceremoniał picia kawy, a więc nie sposób zbudować międzyosobową relację w badanym przez autorkę środowisku bez uczestnictwa w tym niezwykle ważnym, codziennym obyczaju. Jak się bowiem okazuje, tak prozaiczna czynność jak picie kawy może stanowić platformę kontaktu, wymiany myśli, doświadczeń i „otwarcia” się poznawczo-emocjonalnego na badacza (ale też badacza na badanych). 
towane badania to nie monolog, lecz interakcja pozwalająca na szczerość, otwarcie się i integralność uczestniczących podmiotów. Tak zorientowane projekty badawcze akcentują konstruktywną, interpersonalną, podmiotową relację badacz - badany. W konsekwencji badacz nie jest arbitralnym decydentem w procesie badawczym, ponieważ indygeniczny projekt badań jest wypadkową relacji i trwającej konwersacji między badaczem a społecznością. To, z kolei, generuje wyjątkowe teoretyczne i metodologiczne umocowanie, zmieniając status relacji członków danej społeczności w procesie poszukiwania wiedzy (proces tzw. rethiking communities). Taka relacja w dynamice badań pozwala m.in. odpowiedzieć na pytania, jaki aspekt danej rzeczywistości jest wart dalszej eksploracji, co można etycznie zrobić, by tę wiedzę zdobyć i jak zostanie ona wykorzystana. Uwzględnienie tych kwestii pozwala osadzić badanie w określonym kontekście kulturowym bez obawy o błędy nadinterpretacji czy generalizacji otrzymanych wyników.

W projektowaniu i realizacji projektów badawczych warto więc unikać podporządkowania wkładu społeczności lokalnych do badań, tworząc $\mathrm{z}$ nich raczej fundament narracji, ponieważ badani to nie tylko informatorzy czy źródło danych, ale to przecież oni, przez swoje praktyki kulturowe dnia codziennego, tworzą tę wiedzę (tzw. community of learners), [Wilson 2008: 61]. Co więcej, ponieważ idee rozwijają się przez relacje, które łączą badacza z otoczeniem społecznym podlegającym oglądowi, budowanie relacji dokonuje się przez znaną w metodologii jakościowej narrację (storyteling), [Sefa Dei 2013: 29].

Podjeście indygeniczne warto uczynić postulatem, a zarazem głosem w dyskusji nad badaniami w przestrzeni międzykulturowej ze względu na upodmiotowienie procesu poznania i samych badań. Warto też mieć na uwadze, iż kontekst kulturowy wpływa na konstruowanie narzędzi metodologicznych, przez co analiza faktów pedagogicznych musi być prowadzona $\mathrm{z}$ ich uwzględnieniem, co w rezultacie „sprzyja rozumieniu istoty i motywów ludzkich zachowań, pozwalając na lepsze wzajemne porozumienie i budowanie związków z kulturą" [Przyborowska 2010: 432]. Pewną oczywistością może być stwierdzenie, iż kultura wyznacza horyzont znaczeń, jakie nadajemy otaczającej rzeczywistości, z całym jej materialnym i duchowym uwarunkowaniem. I choć badania naukowe to też swoista ontologiczna, osobista podróż podporządkowana owemu horyzontowi kulturowemu, to od wyobraźni i gotowości badacza zależy, czy zechce przełamać duszący epistemologicznie paradygmat europocentryczny. 


\section{Bibliografia}

Broz S. (2002), Dobrzy ludzie w czasach zła, Wołowiec

Buchowski M., Burszta W.J. (1993), Antropologia Kognitywna: charakterystyka orientacji, [w:] M. Buchowski (red.), Amerykańska Antropologia Kognitywna. Poznanie, język, klasyfikacja i kultura, Warszawa

Czerepaniak-Walczak M. (2010), Badanie $w$ działaniu, [w:] S. Palka (red.), Podstawy metodologii badań w pedagogice, Gdańsk

Heron J. (1991), Philosophical basis for a new paradigm, [w:] P. Reason, J. Rowan (red.), Human inquiry. A sourcebook of new paradigm research, Chichester-New York-Brisbane-Toronto-Singapore

Hofstede G. (2001), Culture's consequences: comparing values, behaviours, institutions, and organizations cross nations, Thousand Oaks

Kubinowski D. (2010), Jakościowe badania pedagogiczne. Filozofia-Metodyka-Ewaluacja, Lublin

Malewski M. (red.), (1998), Teorie andragogiczne. Metodologia teoretyczności dyscypliny naukowej, Wrocław

Markešić L. (2009), Kako živjeti zajedno?, Sarajevo

Matsumoto D., Juang L. (2007), Psychologia międzykulturowa, Gdańsk

Melosik Z. (2007), Teroia i praktyka edukacji wielokulturowej, Kraków

Nisbett R.E. (2001), Geografia myślenia. Dlaczego ludzie Wschodu i Zachodu myśla inaczej, Sopot

Padilla A.M. (2004), Quantitative Methods in Multicultural Education Research, [w:] J. A. Banks, C. A. McGee Banks (red.), Handbook of Research on Multicultural Education, San Francisco

Przyborowska B. (2010), Kulturowe uwarunkowania badań pedagogicznych, [w:] S. Palka (red.), Podstawy metodologii badań w pedagogice, Gdańsk

Reason P, Rowan J. (red.), (1991), Human inquiry. A sourcebook of new paradigm research, Chichester-New York-Brisbane-Toronto-Singapore

Rogler L.H. (1989), The meaning of culturally sensitive research in mental health, "American journal of Psychiatry" 146(3)

Sefa Dei G.J. Sefa Dei (2013), Critical Perspectives on Indigenous Research, "Socialist Studies - The Journal of the Society for Socialist Studies" t. 9(1)

Sefa Dei G.J. (2013), The Black Scholar, [w:] The Encyclopedia of African Cultural Heritage, M.J. Shujaa, K. J. Shujaa, Thousand Oaks

Stewart L. (2012), Commentary on Cultural Diversity Across the Pacific: The Dominance of Western Theories, Models, Research and Practice in Psychology, "Journal of Pacific Rim Psychology" t. 6, nr 1

Szkudlarek T. (1997), Poststrukturalizm a metodologia pedagogiki, „Socjologia Wychowania" z. 317

Wilson S. (2008), Research is Ceremony. Indigenous Research Methods, Halifax

Yoder, J. D., Kahn A. S. (1993), Working toward an inclusive psychology of women, "American Psychologist" nr 48 


\section{SumMARY}

\section{Indigenous perspective in researching culturally diverse communities - towards methodological cultural sensitivity}

The article tackles the issue of methodological paradigms in research on multicultural education. It embraces reflections over the traditional approach engaging biased, europocentric stand, often questioning the principle of the equality of cultures, but on the other hand provides with a proposal of introduction of the indigenous model to the widely perceived practice of constructing and conducting intercultural research projects. Such perspectives allows the researched communities to participate actively in the process of research at each stage, contributing to the dissemination of knowledge taking into account cultural difference, hence being culturally conscious. An example of own researching experiences from the region of Bosnia-Herzegovina is provided in the context of appropriate preparation for indigenous approach in research. The author additionally proposes a set of specific competences and soft skills which facilitate such approach if manifested by the researcher, to recall openness, flexibility, adaptation skills and open-mindedness for instance.

\section{Keywords:}

indigenous research, cultural diversity, Europocentric research paradigm, researcher's soft skills, Bosnia-Herzegovina, cultural borderland 